\title{
Opinions of Library Science PhD's About Requirements for the PhD Degree in Library Science
}

\begin{abstract}
Opinions were sought from all holders of PhD degrees in library science concerning the most desirable elements of the doctoral programs in the library schools. Ninety-six PhD's responded. Their replies on such matters as entrance requirements, course requirements and content, language requirements, examination practices, and dissertation topics are tabulated and presented.
\end{abstract}

\begin{abstract}
A All members of the American Library Association holding $\mathrm{PhD}$ degrees in library science were polled recently on certain facets of the requirements for this degree. Ninety-six anonymous responses were received from 151 questionnaires mailed. Thirty-five of these respondents held their $\mathrm{PhD}$ degrees from the University of Chicago; twenty were from Illinois; thirty-two were from Michigan; seven were from Rutgers. One each were from Case Western Reserve and Wisconsin. The latter two were eliminated for ease of tabulation.

The " 30 s, 40s," etc., in the following tables refer to the decade in which the respondent received his $\mathrm{PhD}$ degree. "Ed" in the tables means that he is engaged primarily in library education; "Ad" means that he is primarily a library administrator; and "Ret" indicates that he is retired. Forty-five of the respondents were engaged primarily in li-
\end{abstract}

Dr. Slavens is Assistant Professor of Library Science in the University of Michigan. brary education; forty-six were administrators; and three were retired. The following is a summary of these responses.

\section{Admissions}

The first question had to do with the minimal degree requirements for admission to the PhD program. Sixty-eight per cent of the respondents thought that this should be the master's degree from an accredited library school. In responses to this question, as in many others, however, many suggested that flexibility be exercised. For example, several suggested that a person with a degree in mathematics or engineering be admitted to the $\mathrm{PhD}$ program without any library education. Another person suggested that the requirement for a library degree be waived for a person with significant professional library experience. The responses to this question are shown in Table 1.

The second question had to do with the minimal grade point average required for admission. Forty-three per cent of the respondents thought that a 
TABLE 1

Minimal Degree Requirements for Admission

\begin{tabular}{|c|c|c|c|c|c|c|c|c|c|c|c|c|c|c|}
\hline & \multicolumn{6}{|c|}{ Chicago } & \multicolumn{2}{|c|}{ Illinois } & \multicolumn{3}{|c|}{ Michigan } & \multirow{2}{*}{\multicolumn{2}{|c|}{$\frac{\text { Rutgers }}{60 \mathrm{~s}}$}} & \\
\hline & & $30 \mathrm{~s}$ & & $40 \mathrm{~s}$ & $50 \mathrm{~s}$ & $60 \mathrm{~s}$ & $50 \mathrm{~s}$ & $60 \mathrm{~s}$ & & $50 \mathrm{~s}$ & $60 \mathrm{~s}$ & & & \\
\hline & 茴 & 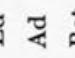 & 茞 & $\frac{\pi}{4}$ & 苗 & 苗 & 画 & 苗 & 范 & & & $\pi$ & & \\
\hline None & & & & & & & & & 1 & & 1 & & & 2 \\
\hline Bachelor's degree & 1 & & & 1 & 1 & & & 2 & & & & & & 5 \\
\hline $\begin{array}{l}\text { BLS from an unaccredited or } \\
\text { accredited library school }\end{array}$ & & & & 1 & & 1 & & & & 1 & & & & 3 \\
\hline $\begin{array}{l}\text { BLS from an accredited library } \\
\text { school }\end{array}$ & & & 1 & 1 & 1 & 1 & 1 & 1 & & 1 & & & & 7 \\
\hline Master's degree in any field & & & 1 & 1 & & & & 1 & 1 & & & 12 & 2 & 7 \\
\hline $\begin{array}{l}\text { Master's degree from an unaccredited } \\
\text { or accredited library school }\end{array}$ & & & 1 & & 14 & & & 1 & & 1 & 2 & & & 10 \\
\hline $\begin{array}{l}\text { Master's degree from an accredited } \\
\text { library school }\end{array}$ & 1 & 12 & 23 & 3 & 42 & 1 & 24 & 25 & 2 & 16 & 62 & 32 & 24 & 46 \\
\hline $\begin{array}{l}\text { Master's degree from an accredited } \\
\text { lib. school plus a subject master's }\end{array}$ & & & & & 1 & & & & & 25 & 53 & & & 13 \\
\hline $\mathrm{BLS}$ or a $\mathrm{PhD}$ in a subject field & & & & & & & 1 & & & & & & & 1 \\
\hline
\end{tabular}

TABLE 2

Minimal Graduate Grade Point Average Requirements for Admission

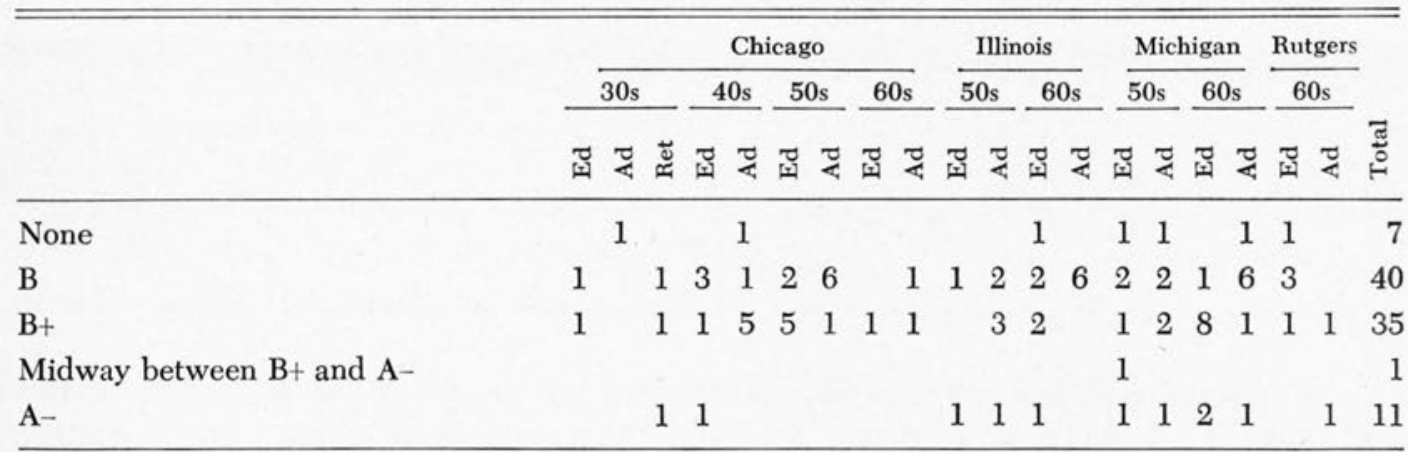

B grade was sufficient, while 37 per cent favored a $\mathrm{B}+$. Six per cent agreed with the person who wrote pungently, "Forget the damned grades." In this connection, it is interesting to note that administrators were willing to admit people with lower grade point averages than were educators. Several respondents felt that the institution from which the degree was earned was important as well as the grade point average. The responses to this question are reported in Table 2.
The next question on admissions was concerned with which examinations should be required for evaluating a student's suitability for the PhD program. Forty-nine per cent thought that the Graduate Record Examination should be required, while 24 per cent favored both the Graduate Record Examination and the Miller Analogies Test. In other words 73 per cent favored at least the Graduate Record Examination. The responses to this question are noted in Table 3. On the issue of the number of years 
TABLE 3

Examination Requirements for Evaluating Students' Suitability for Admission

\begin{tabular}{|c|c|c|c|c|c|c|c|c|c|c|c|c|}
\hline & \multicolumn{5}{|c|}{ Chicago } & \multicolumn{2}{|c|}{ Illinois } & \multicolumn{2}{|c|}{ Michigan } & \multicolumn{3}{|c|}{ Rutgers } \\
\hline & $30 \mathrm{~s}$ & & $40 \mathrm{~s}$ & $50 \mathrm{~s}$ & $60 \mathrm{~s}$ & $50 \mathrm{~s}$ & $60 \mathrm{~s}$ & $50 \mathrm{~s}$ & $60 \mathrm{~s}$ & & $60 \mathrm{~s}$ & \\
\hline & 苗 & 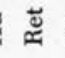 & 苗 & 苗 & 용 운 & 舲 & 承 & 苗 & 再 & 进 茴 & 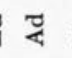 & : \\
\hline None & & & 1 & 1 & & & & & 3 & & 1 & 7 \\
\hline $\begin{array}{l}\text { Graduate Record Examination } \\
\text { and Miller Analogies Test }\end{array}$ & 21 & 1 & 1 & 22 & 1 & 1 & 2 & 21 & 32 & 21 & 1 & 23 \\
\hline Graduate Record Examination & & & 45 & 44 & 1 & 23 & 34 & 43 & 51 & 13 & & 46 \\
\hline Miller Analogies Test & & & & 1 & & & 1 & & 1 & & & 3 \\
\hline No response & & 2 & 1 & & 1 & 2 & 2 & 2 & & 5 & & 15 \\
\hline
\end{tabular}

TABLE 4

Professional Library Experience Requirements for Admission

\begin{tabular}{|c|c|c|c|c|c|c|c|c|c|c|c|c|c|c|c|c|c|}
\hline & \multicolumn{8}{|c|}{ Chicago } & \multicolumn{3}{|c|}{ Illinois } & \multicolumn{4}{|c|}{ Michigan } & & \multirow{3}{*}{ ప్లّ } \\
\hline & & $30 \mathrm{~s}$ & & 4 & $0 \mathrm{~s}$ & 50 & & $\overline{60 s}$ & 5 & $0 \mathrm{~s}$ & $\frac{60 \mathrm{~s}}{}$ & & $50 \mathrm{~s}$ & $\overline{60 s}$ & & & \\
\hline & تี & $\frac{7}{4}$ & $x$ & 7 & व & Tี & 8 & एี & 茞 & $\frac{\pi}{4}$ & 78 & 龟 & $\frac{\pi}{4}$ & ت 3 & ? & 串莚 & \\
\hline None & 2 & & & 3 & 2 & 3 & 1 & 1 & 1 & 2 & 41 & 3 & 3 & 5 & 2 & 31 & 37 \\
\hline One year & & 1 & 1 & & 1 & 1 & 2 & & & & & & 1 & & & 1 & 8 \\
\hline Two years & & & 1 & 1 & 2 & 3 & 2 & 1 & 1 & & 13 & 1 & & 1 & 3 & 11 & 22 \\
\hline Three years & & & 1 & 1 & 1 & & 1 & 1 & & 3 & 11 & 2 & & 3 & 3 & & 18 \\
\hline Four years & & & & & 1 & & 1 & & & & & & & & & & 2 \\
\hline Five years & & & & & & & & & & 1 & 1 & & 2 & 2 & 1 & & 7 \\
\hline
\end{tabular}

of professional library experience which should be required for admission, there was considerable difference of opinion. Forty per cent thought that no experience should be required, while the balance would require at least one year. Some thought that the variety and the quality of the experience should be evaluated. Others believed that related experience, such as teaching in college, should be counted in lieu of library experience. The results on the question about experience are noted in Table 4 .

\section{Courses}

The next section of the questionnaire dealt with the amount of course work required in a doctoral program. Al- though 26 per cent thought that there should be no required minimum, most of the people who responded did not think this much flexibility was desirable. Sixty-two per cent thought that the course work should total at least twenty hours. The responses to this question are reported in Table 5.

In one of the stronger expressions of opinion, 71 per cent indicated that the courses taken in the library school by $\mathrm{PhD}$ students should cover the whole field of librarianship. Only 26 per cent thought that they should be restricted to the student's area of specialization. One respondent wrote that the program should center on creative effort through individual research, not on classroom in- 
TABLE 5

Minimal Number of Semester Hours of Course Work in Library Science Beyond the Fifth Year Degree in Library Science

\begin{tabular}{|c|c|c|c|c|c|c|c|c|c|c|c|c|c|c|c|}
\hline & \multicolumn{7}{|c|}{ Chicago } & \multicolumn{3}{|c|}{ Illinois } & \multicolumn{3}{|c|}{ Michigan } & \multicolumn{2}{|c|}{ Rutgers } \\
\hline & \multicolumn{2}{|c|}{$30 \mathrm{~s}$} & \multicolumn{2}{|c|}{$40 \mathrm{~s}$} & $50 \mathrm{~s}$ & \multicolumn{2}{|c|}{$60 \mathrm{~s}$} & $50 \mathrm{~s}$ & \multicolumn{2}{|c|}{$60 \mathrm{~s}$} & $50 \mathrm{~s}$ & \multicolumn{2}{|c|}{$60 \mathrm{~s}$} & $\overline{60 \mathrm{~s}}$ & \\
\hline & 苟 进 & & 苗: & 83 & च & $\widetilde{\Phi}$ & $\because 2$ & تृ & 苗 & $\pi$ & & 苟 & 进 & تृ & : \\
\hline No minimum & 2 & & 2 & & 32 & 1 & 1 & 1 & 1 & 1 & 32 & 2 & 3 & 1 & 25 \\
\hline $0-19$ & & & & & & & & & & & 2 & & & & 2 \\
\hline 20-29 & & 2 & & 11 & 12 & & 1 & 1 & 2 & 2 & 11 & 4 & 3 & 2 & 23 \\
\hline $30-39$ & & & 2 & 41 & 13 & & & 24 & 3 & 2 & 2 & 3 & 1 & 21 & 30 \\
\hline $40-49$ & & 1 & 1 & & 1 & & & & & & 1 & & & 1 & 5 \\
\hline $50-59$ & & & & & 1 & & & & & & & & & & 1 \\
\hline $60-69$ & & & & & & & & & & 1 & & & & & 1 \\
\hline No response & 1 & & & 2 & & & & & & & & & 2 & 2 & 7 \\
\hline
\end{tabular}

TABLE 6

Content of the Courses Taken in the Library School

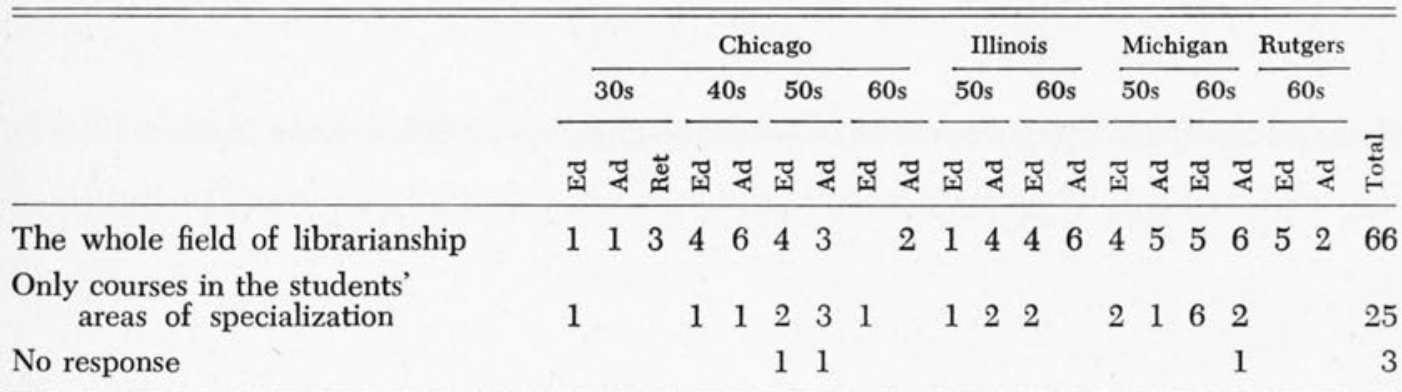

struction. The responses to the question on the content of the courses are summarized in Table 6.

Most of the respondents favored the use of several seminars among these courses. One person, for example, wrote that a methodologically oriented seminar might well be the backbone of a quality program. Another suggested that these seminars should force the student to speak, write, and defend in competition with his peers and under the tough leadership of a faculty member. Sixtyeight per cent thought that the percentage should be at least 30 . The responses to this question on seminars are summarized in Table 7.

On the related question of foreign languages, 58 per cent thought that two should be required, while 25 per cent favored one. Some thought that a collateral field-statistical methods or computer programming-could be substituted for one of these languages. A few of these respondents thought that competence in one language is preferable to a reading knowledge of two. Others would require only those languages which are needed in the student's research. The responses on the number of foreign languages to be required are reported in Table 8 .

\section{Preliminary Examinations}

As to the form of the preliminary examinations, 72 per cent thought that 
TABLE 7

Percentage of the Courses to Be in the Form of Seminars

\begin{tabular}{|c|c|c|c|c|c|c|c|c|}
\hline \multicolumn{4}{|c|}{ Chicago } & \multicolumn{2}{|c|}{ Illinois } & \multicolumn{2}{|c|}{ Michigan } & \multirow{2}{*}{$\frac{\text { Rutgers }}{60 \mathrm{~s}}$} \\
\hline $30 \mathrm{~s}$ & $40 \mathrm{~s}$ & $50 \mathrm{~s}$ & $60 \mathrm{~s}$ & $50 \mathrm{~s}$ & $60 \mathrm{~s}$ & $50 \mathrm{~s}$ & $60 \mathrm{~s}$ & \\
\hline
\end{tabular}

\begin{tabular}{|c|c|c|c|c|c|c|c|c|c|c|c|c|c|c|c|c|}
\hline None & & & & & & & & & & & & & & & & \\
\hline $10-30$ & 1 & 1 & 2 & 3 & & 3 & & & & 3 & & & 1 & 1 & & \\
\hline $30-50$ & 1 & 2 & 1 & 2 & 3 & 2 & & & 3 & & & 2 & 25 & 4 & 1 & \\
\hline $50-70$ & & & 1 & 1 & 1 & 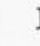 & & & 2 & 2 & & & 13 & & & \\
\hline $70-90$ & 1 & & & 1 & & & & & & & & & 13 & 1 & 1 & \\
\hline $90-100$ & & & & 1 & & & & & & 1 & L & 1 & & & & \\
\hline No response & & & 1 & & 2 & 2 & 2 & 1 & 1 & & L & & 1 & 2 & 1 & \\
\hline
\end{tabular}

TABLE 8

Foreign Language Requirements

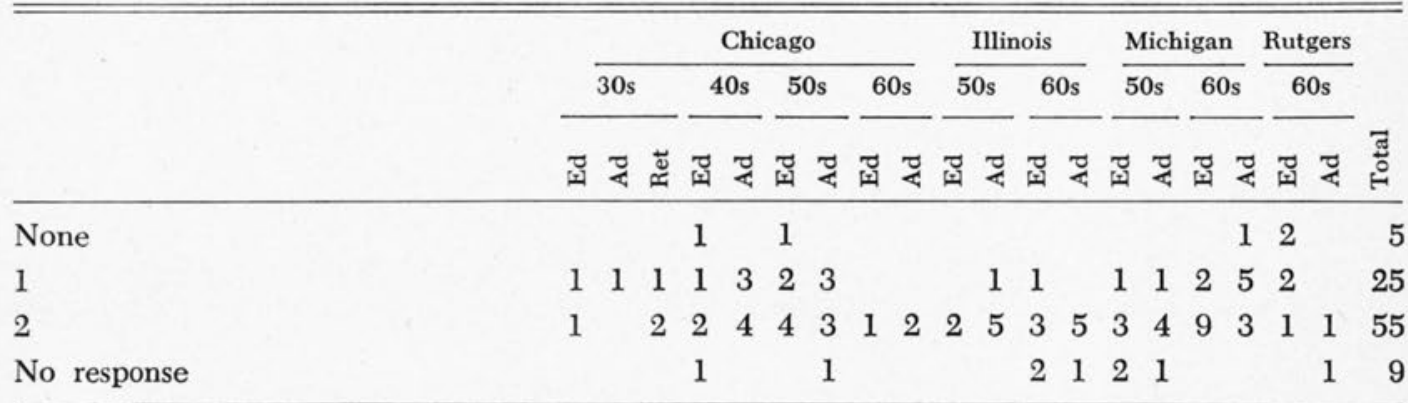

they should include both written and oral questions, while 22 per cent thought that all of them should be written. Only 2 per cent thought that all the examinations should be oral. In this connection, one person volunteered the suggestion that the oral examination should include matters which had been covered on the written examinations but which the faculty felt needed to be clarified or elaborated upon and that it should also include technical matters concerning the dissertation. Another person suggested that an oral examination helps to reveal personal qualifications which would help in determining potentiality to carry a dissertation to a successful completion. Another felt that the decision as to the oral or written nature of the exam- inations should be based on the field of specialization. He pointed out, for example, that it may be important for an administrator to be able to field questions. Another person dismissed oral examinations as "horrible experiences" which favor the "glib student with a gift of gab." The responses on this matter are recorded in Table 9.

Another question related to the numbers of years which should be allowed to elapse before the preliminary examinations would need to be repeated, provided that the thesis was not finished. Fifty-seven per cent thought that this period should be five years. The responses to this question are recorded in Table 10.

Seventy per cent thought that the pre- 
TABLE 9

Form of Preliminary Examinations

\begin{tabular}{|c|c|c|c|c|c|c|c|c|}
\hline & $\mathrm{Chi}$ & ago & & & & Mich & gan & Rutgers \\
\hline $30 \mathrm{~s}$ & $40 \mathrm{~s}$ & $50 \mathrm{~s}$ & $60 \mathrm{~s}$ & $50 \mathrm{~s}$ & $60 \mathrm{~s}$ & $50 \mathrm{~s}$ & $60 \mathrm{~s}$ & $60 \mathrm{~s}$ \\
\hline
\end{tabular}

None

Written

Oral

Partly written and partly oral

No response
1

$1 \quad 3 \quad 1$

1

$\begin{array}{lllllll}3 & 5 & 4 & 2 & 1 & 21\end{array}$

11

$\begin{array}{lllllllllllllllllll}2 & 1 & 1 & 5 & 4 & 5 & 7 & 2 & 2 & 5 & 5 & 6 & 6 & 3 & 6 & 4 & 3 & 1 & 68\end{array}$

1

TABLE 10

Number of Years Should Be Allowed to Elapse

Before the Preliminary Examinations Would NeEd to Be Repeated

\begin{tabular}{|c|c|c|c|c|c|c|c|c|c|c|c|c|c|c|c|c|c|}
\hline & & & \multicolumn{4}{|c|}{ Chicago } & \multicolumn{5}{|c|}{ Illinois } & \multicolumn{3}{|c|}{ Michigan } & \multicolumn{3}{|c|}{ Rutgers } \\
\hline & \multicolumn{2}{|c|}{$30 \mathrm{~s}$} & \multicolumn{2}{|c|}{$40 \mathrm{~s}$} & \multicolumn{2}{|c|}{$\overline{50 \mathrm{~s}}$} & $60 \mathrm{~s}$ & \multicolumn{2}{|c|}{$50 \mathrm{~s}$} & \multicolumn{2}{|c|}{$60 \mathrm{~s}$} & \multicolumn{3}{|c|}{$50 \mathrm{~s} \quad 60 \mathrm{~s}$} & \multicolumn{2}{|c|}{$60 \mathrm{~s}$} & \\
\hline & 茴 & 苂 & Tี & $\pi$ & 记 & & ت & 完 & $\pi$ & 菌 & & & 苟 & $\pi$ & $\widetilde{0}$ & ¿ & : \\
\hline 2 & & & & & & & & & & & & & & & & 1 & 1 \\
\hline 3 & & & & 1 & & & & & & & & 1 & & & & & 2 \\
\hline 4 & & & & & & & & & & 1 & & & & 1 & & & 2 \\
\hline 5 & 2 & 3 & 4 & 3 & 23 & 3 & 11 & 2 & 2 & 45 & & 52 & 6 & 5 & & 1 & 54 \\
\hline 6 & & & & & 1 & & & & 1 & & & & 2 & & 1 & & 5 \\
\hline 7 & & & & 3 & 23 & 3 & 1 & 1 & 1 & & & 2 & 2 & 3 & & & 17 \\
\hline Unlimited & & & & & & & & & 1 & 1 & & & & & & & 2 \\
\hline No response & & 1 & 1 & & 2 & & & & 1 & 1 & & 11 & 1 & & 1 & & 11 \\
\hline
\end{tabular}

liminary examinations should cover the whole field of librarianship. Twentyfour per cent felt that the examinations should cover only the candidate's area of specialization and research methodology. Others believe that the minor fields should also be covered in the preliminary examinations, while still others think that the emphasis of the examinations should be in the area of specialization. Seventy-four per cent favored the inclusion of research methodology in the examinations. The breakdown on the replies to this question as to what the preliminary examinations should cover is reported in Table 11.

\section{THESIS}

In responding to the question as to the type of research appropriate for a $\mathrm{PhD}$ dissertation, one person wrote, "The majority of library history research isn't worth the paper it is printed on. History should be outlawed." His point of view, however, was not common among the respondents. Ninety-six per cent responded that historical research, as well as studies on contemporary problems, is appropriate. Several commented that historical, descriptive, experimental, and statistical research are all acceptable. The breakdown among the 
TABLE 11

Content of the Preliminary Examinations

\begin{tabular}{|c|c|c|c|c|c|c|c|c|}
\hline \multicolumn{4}{|c|}{ Chicago } & \multicolumn{2}{|c|}{ Illinois } & \multicolumn{2}{|c|}{ Michigan } & \multirow{2}{*}{$\frac{\text { Rutger }}{60 \mathrm{~s}}$} \\
\hline $30 \mathrm{~s}$ & $40 \mathrm{~s}$ & $50 \mathrm{~s}$ & $60 \mathrm{~s}$ & $50 \mathrm{~s}$ & $\overline{60 \mathrm{~s}}$ & $50 \mathrm{~s}$ & $\overline{60 \mathrm{~s}}$ & \\
\hline
\end{tabular}

Research methodology and the whole field of librarianship

$\begin{array}{lllllll}1 & 1 & 1 & 2 & 5 & 4 & 3\end{array}$

$\begin{array}{lll}1 & 2 & 1\end{array}$

$\begin{array}{llllll}2 & 2 & 1 & 1 & 3 & 1\end{array}$ $\begin{array}{llllllllllll}2 & 2 & 3 & 2 & 3 & 3 & 2 & 6 & 2 & 4 & 2 & 48\end{array}$

$\begin{array}{llllllllll}1 & 2 & 2 & 1 & 3 & 1 & 4 & 1 & & 19\end{array}$

$\begin{array}{lllllll}1 & 2 & 1 & 2 & 1 & 4 & 2\end{array}$

23

The candidate's area of specialization only

Candidate's area of specialization and cognate field

TABLE 12

Content of Theses

\begin{tabular}{|c|c|c|c|c|c|c|c|c|}
\hline \multicolumn{4}{|c|}{ Chicago } & \multicolumn{2}{|c|}{ Illinois } & \multicolumn{2}{|c|}{ Michigan } & \multirow{2}{*}{$\frac{\text { Rutger }}{60 \mathrm{~s}}$} \\
\hline $30 \mathrm{~s}$ & $40 \mathrm{~s}$ & $50 \mathrm{~s}$ & $60 \mathrm{~s}$ & $50 \mathrm{~s}$ & $60 \mathrm{~s}$ & $50 \mathrm{~s}$ & $60 \mathrm{~s}$ & \\
\hline
\end{tabular}

Research on contemporary problems only

Historical research and research on contemporary problems

replies to this question is given in Table 12.

\section{WeAKNesses and Strengths of the PhD Programs}

A final question had to do with the weaknesses and strengths of the several $\mathrm{PhD}$ programs. In this connection, many thought that individualized, flexible requirements, scheduling, and instruction were high points of their study. They were appreciative of the opportunity to build their programs around their own research interests.

Another strength frequently mentioned had to do with the quality of the faculties. Several mentioned, for example, the strong faculty interest in each student and his work. One person, for example, said that his chairman made invaluable suggestions for his thesis in their fortnightly meetings and was always prompt in returning drafts of chapters.

The work in research methods was also highly appreciated. One person, for instance, mentioned that in his program he had learned to evaluate research. Another mentioned that he had developed an attitude of inquiry and had developed some ability to identify problems in need of research. Another said that he had learned much about writing from his thesis work. Participation in projects being carried out at the library school was also mentioned favorably. 
The seminars in which students were free to express themselves and to criticize each other's ideas as well as existing practices in the field also received approbation. One person wrote:

Perhaps the best one can hope for in any doctoral program is thorough education in research methodology and the exchange of ideas through vigorous discussion with one's advisor and fellow doctoral students. One learns in that process that he must defend his views in an adequate and competent manner with a careful consideration of all the data.

Other attributes singled out for favorable comment were the opportunities to study in other subject areas of the graduate schools and the excellent libraries available.

The weaknesses listed were parallel to these strengths. Many respondents indicated a desire for more flexibility and opportunities for specialization. Several people also suggested that the programs be aimed more directly at the doctoral students rather than having the students take the same courses as master's degree candidates. In this connection, one person criticized the doctoral program at his school for having been developed on an expedient basis.

The faculties were also criticized for their lack of understanding of librarianship and for their lack of ability to relate to the students' research. One person, for instance, wrote:

Though I had some superb scholar-teachers, there were also those who wouldn't have known what research was if it had hit them in the face. Moreover, even the good ones left a lot to be desired when it came to their own productivity researchwise. They were more concerned with being on an ALA committee or doing some survey for public or college libraries.

Another person criticized his faculty for lack of direction in the writing of his thesis.

Many of the respondents thought that more emphasis on statistical research methodology was needed. Some also would have liked more computer skills. Others criticized their schools for failing to help them to identify current problems. The lack of seminars was also frequently mentioned. Finally, the programs were criticized for their failure to take advantage of interdisciplinary programs at the universities and for their poor physical accommodations.

On the basis of this study it would appear that formal doctoral students tend to favor programs with thorough instruction in research methods, seminars, and opportunities to study outside the library school. At the same time that they favor individualized, flexible requirements, there seems to be no consensus on certain basic requirements. Probably no one would suggest that these requirements should be uniform. The desire for flexible, individualized programs within the schools would also suggest the same type of individualized flexibility among the various programs. 